Japanese Research on Linguistics, Literature, and Culture Vol. 2 No. 1 Nov. 2019, p., 46-59 ISSN Online: 2655-4836

DOI: $10.33633 /$ jr.vlil.3353

http://publikasi.dinus.ac.id/index.php/jrllc/article/view/3353/1834

japanese.research@fib.dinus.ac.id

on Linguistics, Literature and Culture

Published by Universitas Dian Nuswantoro, Semarang

\title{
History and Japanese South Korea Trade Wars
}

\author{
Fahrizal Nugroho, M. Mossadeq Bahri \\ University of Indonesia \\ fahrizalnugroho93@gmail.com
}

Article History: Submitted date 2019-11-27; Accepted date 2019-12-13; Published date 2019-12-26

\begin{abstract}
The trade war between Japan and South Korea is now entering a new phase. South Korea is currently counteracting by boycotting goods originating from Japan, such as FMCG (fastmoving consumer goods) companies, fast retaling and automotive. Japan itself has now downgraded the status of South Korea which was originally included in group $A$ or White List Countries or Preferred Trade Partner List Countries into group B, namely countries and regions participating in international export control regimes and satisfying certain conditions (Excluding those in group A). As we know, this trade war was preceded by restrictions on exports by Japan to South Korea. In July, Japan imposed tighter controls on the export of three raw materials in chips and smart phone screens to South Korea. The materials are photoresists used in the semiconductor industry, hydrogen fluoride as a material for making chips and fluorinated polymides that are used as materials for making smartphone screens. These goods are very important for the industry in South Korea, especially in the smartphone industry, thus making South Korea furious about the Japanese action. The issue that will be raised is how history can shape decision-making in relations between Japan and South Korea, leading to a trade war like today. Relations between Japan and South Korea are very close to what happened in the past. Even today, South Korea still voiced its past suffering caused by Japan and raised tension between the two countries. South Korea plans to file complaints over tightening Japanese export controls to the World Trade Organization (WTO). South Korea accuses Tokyo of having "political motivation" and "discrimination" in the two countries' growing conflict and rooted in wartime history.
\end{abstract}

Keywords : history, trade wars, relation

\begin{abstract}
Abstrak
Perang dagang antara Jepang dan Korea Selatan kini memasuki fase baru. Korea Selatan saat ini memboikot barang-barang yang berasal dari Jepang, seperti perusahaan FMCG (barang konsumen yang dapat terjual dengan cepat), produk retal, dan otomotif. Jepang
\end{abstract}


sendiri sekarang telah menurunkan status Korea Selatan yang semula termasuk dalam kelompok A atau Daftar Putih Negara atau Negara Daftar Mitra Dagang Pilihan ke dalam kelompok B, yaitu negara dan wilayah yang berpartisipasi dalam rezim kontrol ekspor internasional dan memenuhi persyaratan tertentu (Tidak termasuk dalam kelompok A) . Seperti kita ketahui, perang dagang ini didahului dengan pembatasan ekspor oleh Jepang ke Korea Selatan. Pada bulan Juli, Jepang memberlakukan kontrol yang lebih ketat pada ekspor tiga bahan baku dalam chip dan layar ponsel pintar ke Korea Selatan. Bahanbahan tersebut adalah photoresists yang digunakan dalam industri semikonduktor, hidrogen fluorida sebagai bahan untuk membuat chip dan polimida berfluorinasi yang digunakan sebagai bahan untuk membuat layar ponsel pintar. Barang-barang ini sangat penting bagi industri di Korea Selatan, terutama di industri smartphone, sehingga membuat Korea Selatan sangat marah dengan tindakan Jepang. Masalah yang akan diangkat adalah bagaimana sejarah dapat membentuk pengambilan keputusan dalam hubungan antara Jepang dan Korea Selatan, yang mengarah ke perang perdagangan seperti hari ini. Hubungan antara Jepang dan Korea Selatan sangat dekat dengan apa yang terjadi di masa lalu. Bahkan hari ini, Korea Selatan masih menyuarakan penderitaan masa lalunya yang disebabkan oleh Jepang dan meningkatkan ketegangan antara kedua negara. Korea Selatan berencana untuk mengajukan keluhan terkait pengetatan kontrol ekspor Jepang ke Organisasi Perdagangan Dunia (WTO). Korea Selatan menuduh Tokyo memiliki "motivasi politik" dan "diskriminasi" dalam konflik yang tumbuh di kedua negara dan berakar dalam sejarah perang.

Kata kunci: sejarah, perang dagang, relasi

\section{Introduction}

The trade war between Japan and South Korea until now heats up. Because Japan began to applied export restrictions in July. South Korea also announced it would respond Japanese actions (https://www.cnbcindonesia.com/news/20190828163948-4-95438/ini-dia-babak-baruperang-dagang-jagang-korsel). South Korea also accused Prime Minister Shinzo Abe of commenting twice that Korea could not be trusted and treated South Korea like an enemy (https://www.cnbcindonesia.com/news/20190828163948-4-95438/ini-dia-babak-baru-perang- 
dagang-jagang-korsel). Japan applies export limits on chemicals needed by South Korean technology industry such as Samsung, LG and SK Hynix to produce semiconductors and touchscreens on smartphones. These materials include fluorinated polyimides, photoresists , and hydrogen fluoride. In international trade, Japan is the main producer of these three materials. Officials Japan argues that these materials are sent illegally into North Korea to be used as a standard tool weapons manufacturing, but Japan's claims was denied by South Korea (https://tirto.id/perang-dagang-korsel-japan-muka-luka-lama-era-kolonial-egk5). In the latest rules, the exporters of Japan must obtain permission from the relevant authorities before sending the goods to South Korea and the process takes about 90 days. This is very different even for South Korea because previously the process only took one week or 7 days. Even though these raw materials are needed by South Korea's smartphone company.

Aside from Japan's export restrictions, it has also reduced the status of South Korean trading partners from the white list (https://www.meti.go.jp/english/press/2019/ 0802_001.html). Likewise, South Korea also removed Japan from its trade white list partner in September 2019. South Korea also boycotted Japanese products. This boycott was first started among small and medium enterprises (SMEs). Some middle-class department stores in Seoul put stickers that stated they don't sell alcoholic beverages from Japan. More than 23,000 retail outlets have participated in this boycott until July 16, according to one of the company's group leaders to the media (https://www.cnbcindonesia.com/news/20190726113530-487784/warga-korsel-kalap-boikot-segala-barang-berbau-japan). Three large Japanese FMCG ( fast-moving consumer goods ) group companies, Asahi Group Holdings, Kirin Holdings and Sapporo Holdings have stopped their commercial advertisements on television following consumer sentiment in South Korea .

The impact of the political turmoil between the two countries also hit the service sector, especially tourism. In the latest data, travel agency JTB noted a reduction in hotel reservations in Japan by South Korea customers up to $10 \%$. Booking trips to Japan at South Korea's travel agencies has dropped by more than 50\% in July 2019 (https://www.cnbcindonesia.com/news/20190726113530-4-87784/warga-korsel-kalap-boikot- 
segala-barang-berbau-japan). And some South Korean airlines canceled flights from South Korea to Japan.

The source of this problem was last year's trial in November 2018 which contained several Japanese companies who were required to pay compensation to South Korean forced workers during World War II. But the Japanese refused because they assumed that compensation had been paid during the normalization of relations between the two countries. From the background above the question arised, how can history affected foreign policy making towards Japan in the South Korea.

\subsection{Methods}

This paper will use qualitative research methods. Qualitative research is research that produces descriptive data about spoken and written words. Qualitative research is inductive, which focuses on logical procedures that begin with observations which then produce conclusions from general hypotheses. In this case, concepts, ideas are based on patterns found in data. According to Creswell, qualitative research is characterized by information in the form of contextual ties that will lead to models or theories that will explain social phenomena (1994). Data collection techniques that will be used are library research, with sources from secondary data derived from books, online news, reports, articles relating to the problem.

\subsection{Literature Reviews}

The state is a social institution in two different areas but is interrelated with one another, namely the internal and external environment. Internal environment where there are government institutions in a country that interact with each other. Then the external environment, which consists of various countries that interact with each other. Marijke Breuning added that policy makers have always been under the influence of domestic environment and inter $\mathrm{n}$ trai $\mathrm{n}$ in the formulation of foreign policy (Marijke, 2007).

According to Holsti there are several factors that influence policy makers in issuing foreign policy, i.e.(1992).

External factors which include: structure of the system; characteristic/structure of world economy; the policies and actions of other states; global and regional private problems arising from private activities; international law and world opinion. 
Internal factors include: socioeconomic/security needs ; geographical and topographical characteristics; national attributes; government structure and philosophy; public opinion ; bureaucracy ethical consideration.

In his book The Scientific Study of Foreign Policy, James Rosenau said that foreign policy is influenced by internal and external factors. There are five independent variables that can influence foreign policy. First, idiosyncratic leaders individually; second, the role of decision makers; third, governance; fourth, societal sources; fifth, systemic influence (Rosenau, 1980). Societal Sources in the Form of National History.

Rosenau, mentioned that human behavior, both in the form of individuals and a complex system of society is a cumulative result of past experience and part of the impact of stimuli in the present. Characteristics and behavior in a social system is a result of their cultural traditions and their changing environment. The new situation, institutions, expertise, do not necessarily replace the previous patterns that have been formed. Cultural and historical norms are passed down from generation to generation.

Decisions and actions taken by foreign policy makers can be influenced by cultural values and historical events (hisrorical precedents). Actually the role of history has long been a concern, although different terms namely national character or history. Breuning explained that the perspective of actors or policy makers in seeing the world can be shaped and influenced by national history. This is because people and policy makers are formed by their education. National history has an important role through understanding or meanings conveyed through folklore. Starting from this, values are formed and affect new information received by policy makers (Breuning, 2007).

To answer the questions from this case, will focus only on internal factors in foreign policy making. This is because in seeing this case, it will only discuss how the role of history in foreign policy making in South Korea. The response to history also frequently arises in the internal sphere of South Korea.

\section{Discussion}

Japan's victory in the first war China-Japan (1894-1895) and Russo-Japan (1904-1905), is a momentum that makes Japan as a new imperialist power in East Asia and increasingly pushes 
Japan to expand into various countries in. Japan's expansion into South Korea is one of them. At the time of Japan's expansion into South Korea, there were many injuries to the people of South Korea today. It is like Jugun Ianfu or what is called in English in comfort women. This is worsen by the lack of initiative from the Japanese government to recognize the involvement of the Japanese military in the comfort women system and take responsibility for victims of comfort women in South Korea. Japan actually acknowledged the involvement of the Japanese military in the comfort women system in 1993 in a statement called the Kono Statement, however, due to the lack of follow-up from the statement, as well as the subsequent Japanese government which was inconsistent in defending the statement, South Korean people's demands for the Japanese government related to the issue of comfort women continues to roll. The problem is not yet resolved for comfort women, South Korea again demanded Japan to pay compensation to the people of South Korea who were treated as forced laborers during the 1910-1935 war era. The forced laborers did not receive wages or a decent place to live in the war era. Workers are exploited by Japan to build Japanese instruments of war. Many forced workers also even died while working. This dark history led governments to demand that Japan pay compensation to former forced laborers who were South Korean people.

As KJ Holsti said that the state is a social institution in which there are two areas within it, so that international policy produced by the two countries comes from two factors namely internal and external. In this case, the internal factor that pushed South Korea's policy to demand compensation for forced labor carried out by Japan was public opinion. This can be seen from the previous cases, namely the jugun ianfu case since January 1992 every Wednesday in front of the Japanese embassy in South Korea the people of South Korea expressed their disappointment and demands against the Japanese government. Victims of "comfort women" in South Korea held a weekly demonstration. This demonstration then reached its peak in 2011, where demonstrators built a statue symbolizing comfort women right across the Japanese embassy in South Korea, which then attracted a strong reaction from the Japanese government, based on the Vienna Convention on Diplomatic Protocol article 22 (http://legal.un.org/ilc/texts/instruments/english/conventions/9 1 1961.pdf). However, with such public encouragement, the South Korean government cannot do anything about it. 
After many of these public demands, the South Korean government has so far demanded Japan to pay compensation and apologies. But so far the Japanese have never officially apologized to victims during the South Korean war. In this case of forced labor, this demand has been going on since 1997 in Japan (https://www.nytimes.com/ 2013/07/31/ world/asia/south-korean-court-tells-japanese-company-to-pay-for-forced-labor.html).

However, the suit was dismissed by a Japanese court in that year because it was deemed that the 1965 diplomatic normalization agreement was regrettable. In 2012 the South Korean Constitutional Court sent the file back to court and said that Japan's decision was against the South Korean constitution and international legal norms (https://www.nytimes. com/2013/07/31/world/asia/south-korean-court-tells-japanese-company-to-pay-for-forcedlabor.html). South Korea's relations with Japan were again heated up that year. Seeing the increasing antipathy of the South Korean people towards Japan, South Korean President Park Geun-hye, who was officially inaugurated in early 2013, stressed from the beginning of his administration, that Japan must be able to resolve historical conflicts in order to rebuild bilateral relations that forward-looking with South Korea (Glosserman \& Synder, 2015). In July 2013 a South Korean court ordered Mitsubishi Heavy Industries to compensate five South Koreans who were forced to work in company factories during the Japanese colonial period in Korea, which ended in World War II.

Busan High Court ordered the company are to pay $\$ 71,800$ to each of the five Koreans. That was the second decision of a Japanese company in July 2013 . Earlier, the Seoul High Court ordered Nippon Steel and Sumitomo Metal Corporation to pay $\$ 89,800$ to each of the four South Korean plaintiffs to compensate them for forced labor. Nippon Steel and Mitsubishi each said they were planning to appeal. The Busan court said in its ruling that Mitsubishi forced South Korean plaintiffs to work hard in poor conditions in Hiroshima but failed to pay wages, and did not provide shelter or proper food after dropping an atomic bomb there in 1945 . The five plaintiffs have now died and their families they represent them in court. The two decisions are the first to benefit South Korea in a 16-year legal battle carried out in Japan and South Korea, and they can file similar lawsuits from other victims or their families. At least 1.2 million Koreans were forced to work for the Japanese war effort. Around 300 Japanese companies still 
in operation are believed to have used forced labor during the colonial period from 1910-1945 (Glosserman \& Synder, 2015). South Korean demands on new companies gained results in October 2018. The Seoul Supreme Court ruled that a Japanese company must compensate four South Koreans for forced labor during World War II. The Supreme Court in Seoul ordered Nippon Steel \& Sumitomo Metal Corp to pay 100 million won to each of the four plaintiffs. Lee Choon-shik, the only surviving plaintiff, got the decision after waiting more than 5 years for the trial (https://www.liputan6.com/global/read/3680218/koreel-take-company-japan-berichange-dose- to-ex-slave-warf-world-ii).

At the hearing the South Korean court rejected Nippon Steel \& Sumitomo Metal's attitude that the issue of compensation for forced labor had been resolved by the 1965 agreement. The court also rejected the company's argument that it was a different entity from steelmakers who forced South Koreans to work during the war. The South Korean Supreme Court stated that the steel company was formed from the merger of several companies after the war. President Moon Jae-in , who once represented South Korean forced labor as a lawyer in the 2000s, said after taking office last year that the 1965 agreement could not prevent individuals from exercising their right to receive compensation. In the past, both governments have stated that the issue of forced labor compensation has been resolved by the agreement. However President Moon Jae-in also questioned the validity of the 2015 agreement with Japan which was negotiated by the conservative government of South Korea before to compensate South Korean women who were forced into sexual slavery by the Japanese wartime military (https://apnews.com/474886c44d2c498e94e90c0a8abc5f6d). Many South Koreans believe that Seoul received too little in the agreement and called for the dissolution of a foundation known as the Asian Women 's Fund (AWF) in Seoul that was established to support victims with 1 billion yen (\$ 9 million) ) provided by Japan.

From the response of President Moon Jae-in above it is very clear that the policy issued to sue Japan to pay compensation to South Korean forced workers was also motivated by public opinion which often called for compensation for crimes committed by Japan. Although there are indeed other factors that encourage this, but from the explanation above it is very clear that public opinion is also one of the factors that determine in making a foreign policy. After 
that in November on a separate verdict, the court also ordered Mitsubishi to pay up to 150 million won for each of the five plaintiffs or their families (https://www.cnbc.com/ 2018/11/29/south-korea-orders-japans-mitsubishi-to-compensate-wartime-laborers.html). This case from Mitsubishi is also a case that has gone up from 2013.

This was the beginning of Japan's restrictions on exports to South Korea. Relations between the two countries have also worsened that the two countries are boycotting trade products and removing the white list of export partners. The relations between the two countries are indeed closely related to history in the past. This also affects existing public opinion. This can be seen in the figure below.

Figure 1 Japanese And South Korea public opinion 2019

(http://www.genron-npo.net/en/7th-Japan-South\%20KoreaJointOpinionPoll.pdf Is Japan/South Korea a friendly nation?

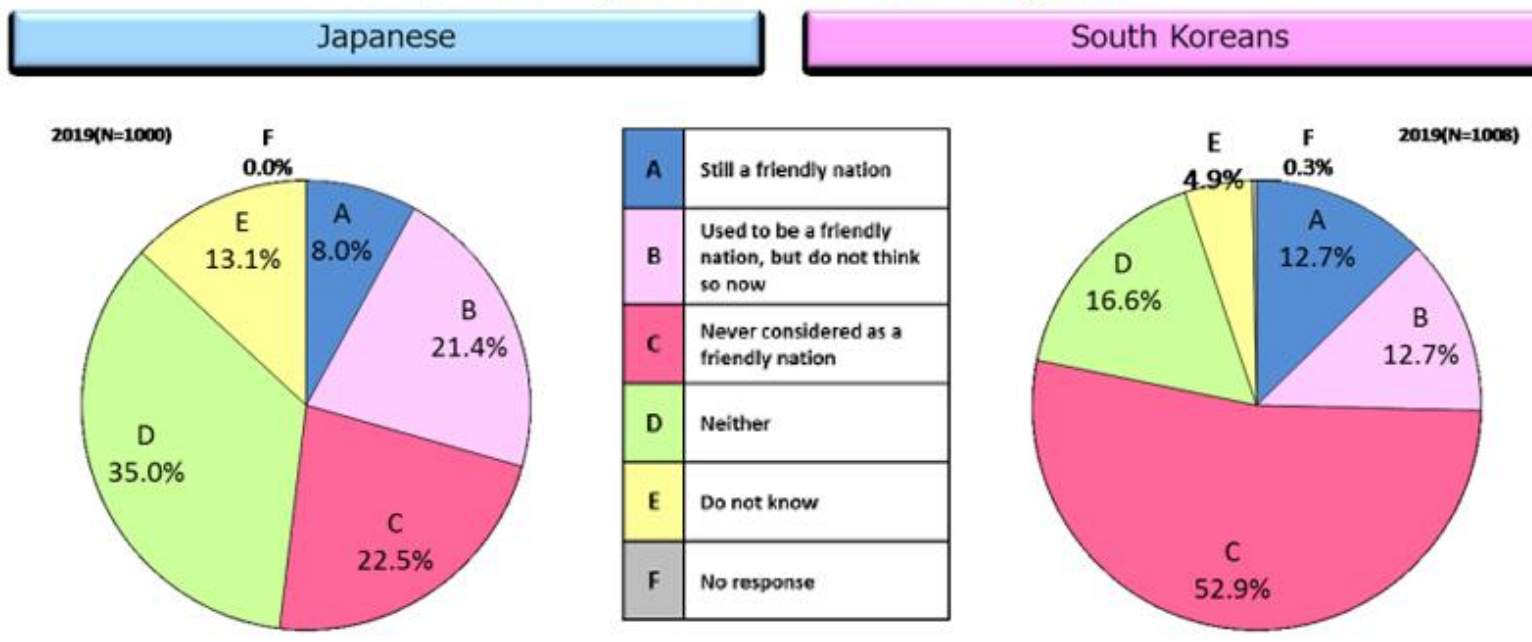

Figure 2 Japanese and South Korea Public Opinion 2016 (http://www.genron-npo.net/pdf/forum_2016_en.pdf ) 
Things to be Done to Better Japan-South Korea Relations

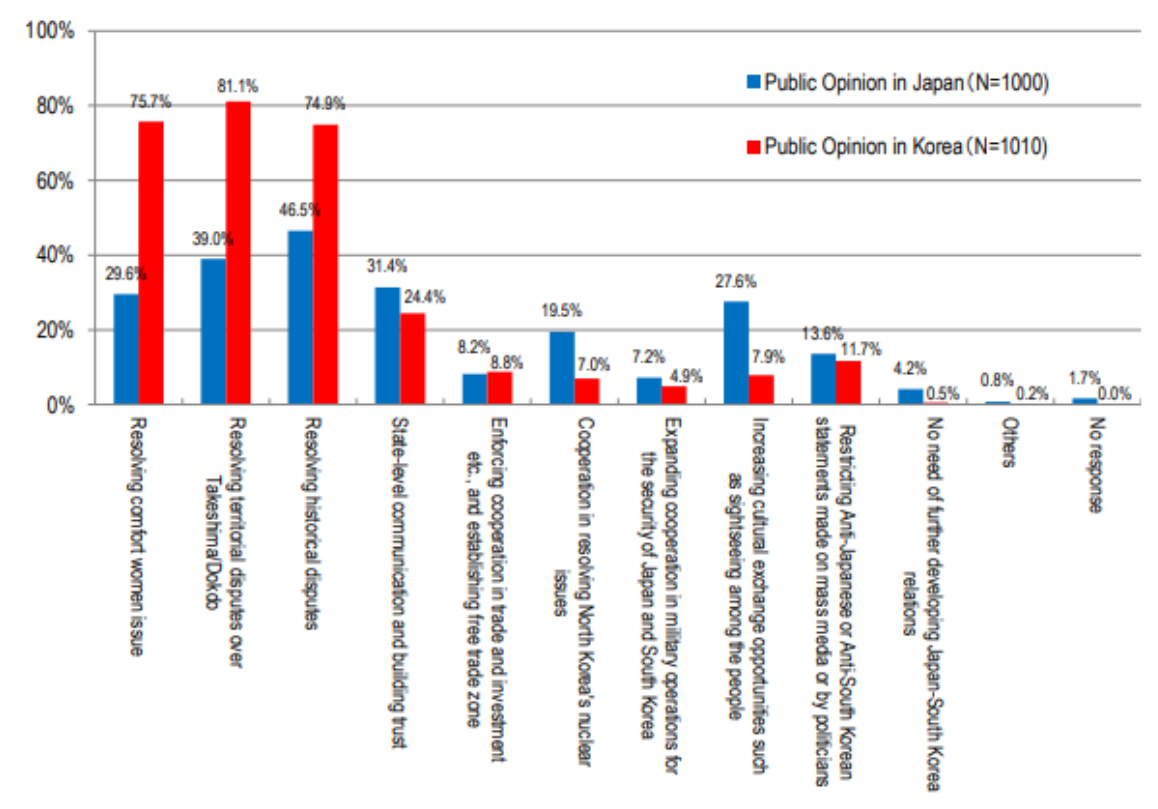

Figure 3 Japan and South Korea Public Opinion (http://www.genron-npo.net/en/archives/170721_en.pdf )

What should be done to develop Japan-South Korea relations?

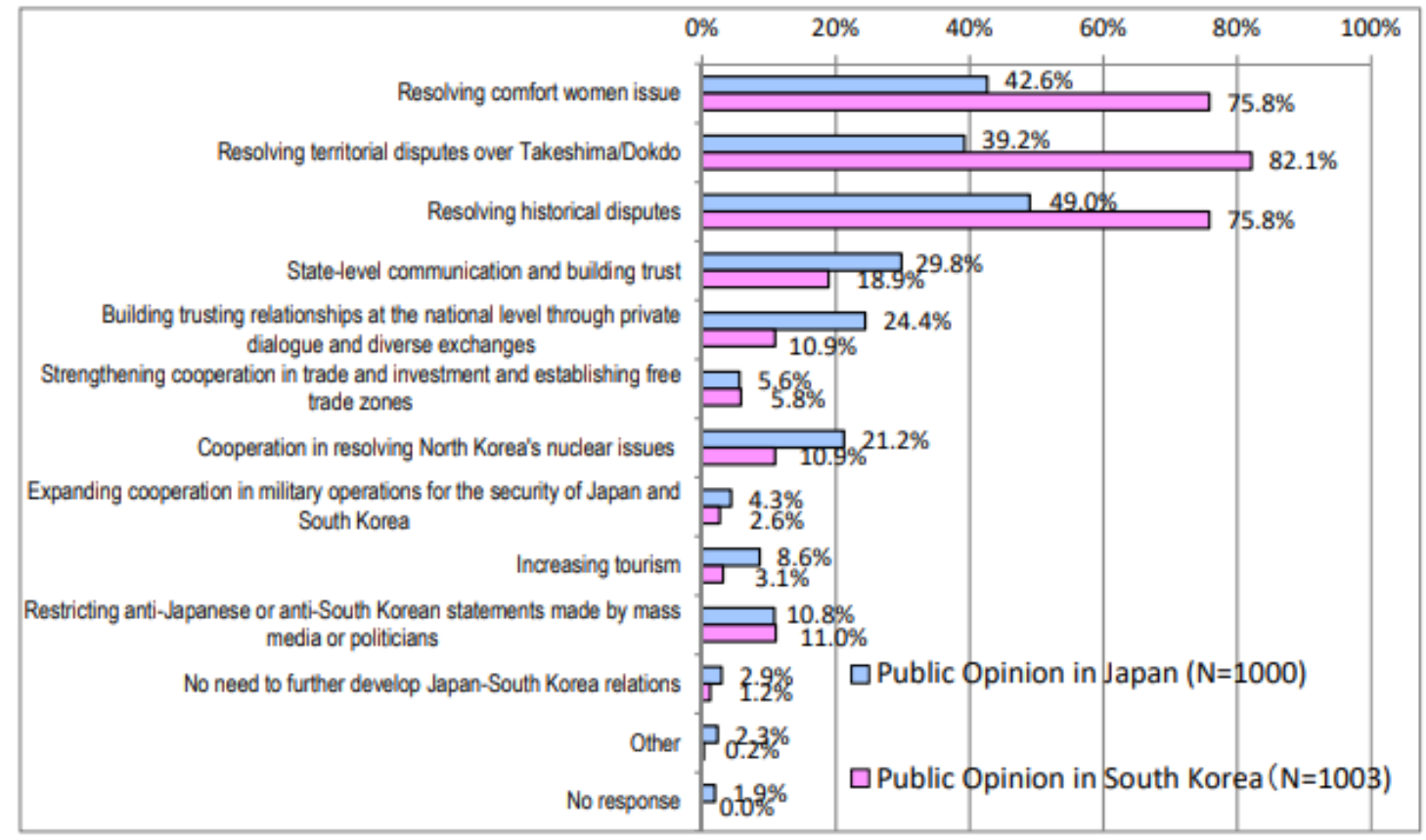

Figure 4 Japanese and South Korea public opinion 2018-2019

(http://www.genron-npo.net/en/7th-Japan-South\%20KoreaJointOpinionPoll.pdf) 


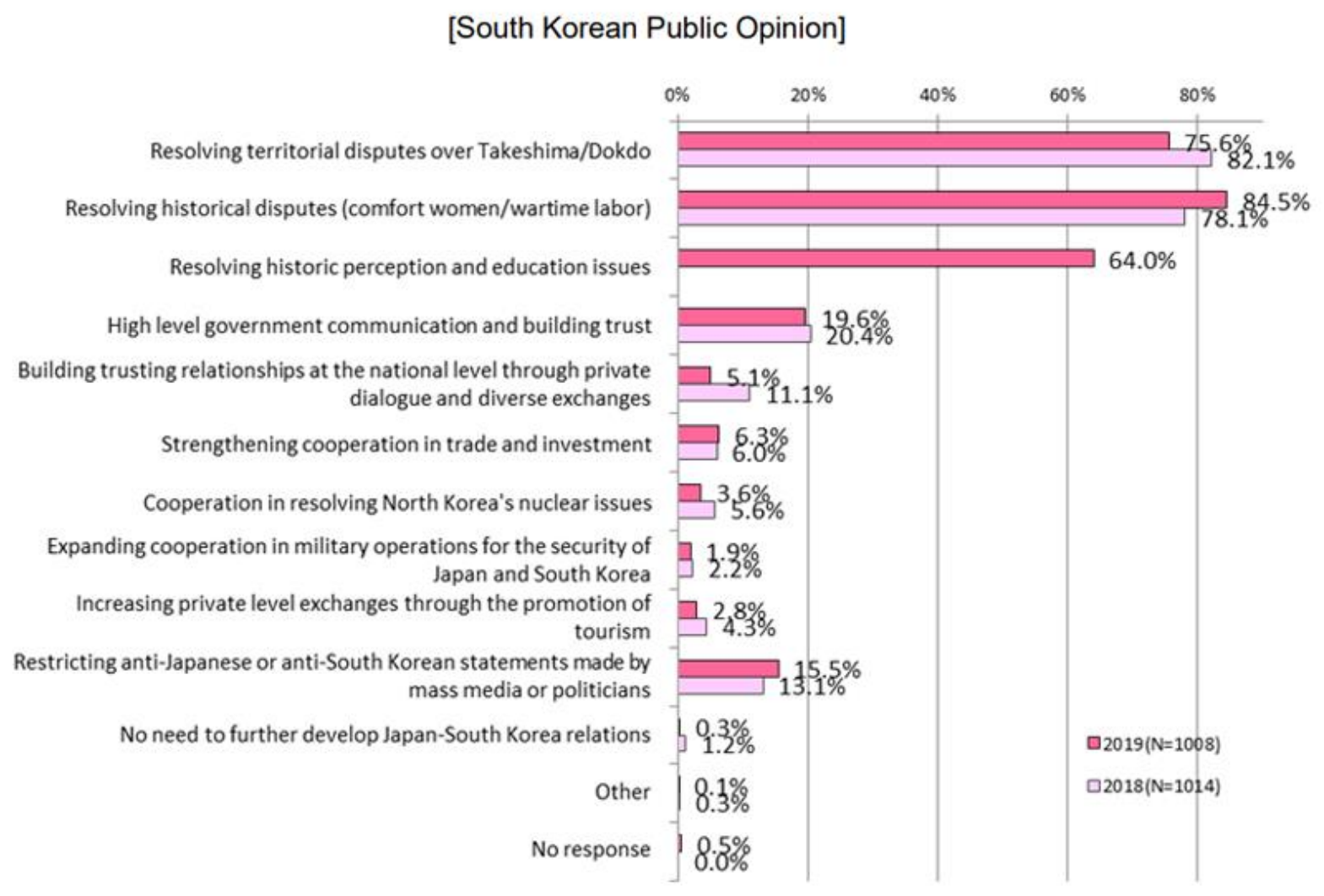

As can be seen above South Korean public opinion it is very clear that South Korean public demands for Japan to solve their historical problems are still very high and even tend to increase from 2018 to 2019. This is as explained by Rosenau that human behavior, both in the form of both the individual and a complex system of society are cumulative results from past experiences and part of the impact of stimuli that are present in the present. Characteristics and behavior in a social system is a result of their cultural traditions and their changing environment. The new situation, institutions, expertise, do not necessarily replace the previous patterns that have been formed. Norma culture and history passed down from generation to generation. This is what is called the historical precedent used by the South Korean government in shaping its foreign policy towards Japan. Officials or the South Korean government not only make foreign policy just to benefit the country, but history also has a large role in making a country's foreign policy.

South Korean public opinion also tends to be more critical of historical times. In figures 2, 3 and 4 it appears that the first 3 problems that have the highest percentage are 
related to history . Although the issue of the Dokdo or Takeshima Islands dispute is a territorial issue, the background of the territorial dust is also a result of past history. Then the second point in the second figure above is resolving historical disputes both comfort women and wartime labor. The laboratories are forced laborers as the case is discussed. Then the third is solving historical perceptions and educational problems. The historical perception referred to in figure 2 above is self-recognition as a Japanese war-time criminal. South Korean society demands the Japanese government to issue an official statement or admit that Japan had become a war criminal in World War II. Recognition as a war criminal is also often a background of heated relations between the two countries. As an example of the Yasukuni Shrine case, when discussions arise about the Yasukuni Shrine it will be very closely related to the tensions that occur between Japan and South Korea. When Japanese officials visit or hold a ceremony at the Yasukuni Shrine to commemorate the souls of Japanese citizens who have sacrificed for the country since 1853 , there will be angry reactions from both South Korea and China (https://www.bbc.com/news/world-asia-25517205). During the Shinzo Abe administration, he had visited Yasukuni shrine twice, and his two visits to Yasukuni shrine had angered both South Korea and China. The reason is that for South Koreans it was a tribute to war criminals during the Pacific War era, but otherwise Japan did not think so. So in the end a negative reaction will always be received by Japan, after visited the Yasukuni Shrine (https://www.bbc.com/news/world-asia-25518166).

Apart from that, solving the problem of education is also one of the topics that have a high percentage of South Korean society. This is caused by history textbooks about Japan in the past many did not write about Japanese crimes against Korea and China. This makes the South Korean people protest because one of Japan's crimes such as forced labor of South Korea (forced labor) or the problem of jugun ianfu or comfort women is not written in the educational textbook (S. Claudia, 2008). In addition, China also demanded that Japan write reality in its textbooks, including Japanese crime in Nanking. Because of this, South Korea also demands to solve educational problems. This is demanded by South Korea so that children in Japan are aware of Japanese war crimes. 
The three issues mentioned above also have a high percentage among South Korean public opinion, which is above 50 percent. Besides these three topics are also a matter of history or the past. Therefore, public opinion and history are both things that are often taken into consideration in the making of a foreign policy, especially towards Japan . Therefore, characteristics and behavior in a social institution or state are a result of a culture or history that is upstream and not just formed. Public opinion on history also tends to increase when viewed from the percentage above, namely on the issue of comfort women or wartime labor in 2016 75.7\% then in 2017 75.8\%, in 2018 78.1\% and in 2019 84, 5\% From the percentage above it can be seen that the characteristics of the people in South Korea who are highly dependent on their history are increasing every year. Therefore, one of the remedies that can be used by Japan is to improve Japan's image of its history to South Korea, or make demands from the people of South Korea such as apologizing formally or compensating victims.

\section{Conclusion}

In a foreign policy making there are always factors that are considered by policy makers. In the case of a trade war between South Korea and Japan, the factors that influenced it were history and public opinion. This is a consideration of the policy makers in making foreign policy towards Japan. The historical factor that the era of World War II until now is considered unresolved by the South Korean side of the relations between the two countries is often heating up. Until the issue of demand for compensation of South Korean forced workers currently still has a relationship with past history. According to Holsti, one of the internal factors that makes South Korea most frequently used against Japan is the issue of war era compensation and official recognition or apology from Japan. Public opinion of Japan's past crimes against South Korea also tends to rise every year. Although there are external factors that tend to worsen relations between the two countries, but internal factors still dominate.

\section{References}

Creswell, John W. (1994). Research Design: Qualitative and Quantitative Approach. California: Sage Publications Inc, pp. 4-7. 
B. Marijke. (2007). Foreign Policy Analysis: A Comparative Introductio. New York: Palgrave Macmillan, pp. 117.

KJ Holsti. (1992). International Politics; A Framework for Analysis. New Jersey: Prentice Hall, pp. 272.

J. Rosenau. (1980). The Scientific Study of Foreign Policy. London: Frances Pinter, 115- 169.

Marijke Breuning. (2007). Foreign Policy Analysis: Comparative Introduction. New York: Palgrave McMillan, pp. 128.

Glosserman, Brad., Scott A. Synder. (2015).The Japan-South Korea Identity Clash. New York: Columbia University Press.

S. Claudia. (2008). The Japanese History Textbook Controversy in East Asian Perspective. The Annuals of the American Academy of Political and Social Science Vol. 617, The Politics of History in Comparative Perspective. pp. 107-122,

https://www.cnbcindonesia.com/news/20190828163948-4-95438/ini-dia-babak-baru-perangdagang-jagang-korsel

https://tirto.id/perang-dagang-korsel-japan-muka-luka-lama-era-kolonial-egk5 https://www.meti.go.jp/english/press/2019/0802_001.html

https://www.cnbcindonesia.com/news/20190726113530-4-87784/warga-korsel-kalap-boikotsegala-barang-berbau-japan

https://www.cnbcindonesia.com/news/20190726113530-4-87784/warga-korsel-kalap-boikotsegala-barang-berbau-japan

http://legal.un.org/ilc/texts/instruments/english/conventions/9_1_1961.pdf

https://www.nytimes.com/2013/07/31/world/asia/south-korean-court-tells-japanese-

company-to-pay-for-forced-labor.html

https://www.nytimes.com/2013/07/31/world/asia/south-korean-court-tells-japanesecompany-to-pay-for-forced-labor.html

https://www.liputan6.com/global/read/3680218/koreel-take-company-japan-beri-changedose-to-ex-slave-warf-world-ii

https://apnews.com/474886c44d2c498e94e90c0a8abc5f6d

https://www.cnbc.com/2018/11/29/south-korea-orders-japans-mitsubishi-to-compensatewartime-laborers.html

http://www.genron-npo.net/en/7th-Japan-South\%20KoreaJointOpinionPoll.pdf

http://www.genron-npo.net/pdf/forum_2016_en.pdf

http://www.genron-npo.net/en/archives/170721_en.pdf

http://www.genron-npo.net/en/7th-Japan-South\%20KoreaJointOpinionPoll.pdf

https://www.bbc.com/news/world-asia-25517205

https://www.bbc.com/news/world-asia-25518166 